\title{
THE 1918 FINNISH CIVIL WAR REVISITED: THE DIGITAL AFTERMATH
}

\author{
Anne Heimo
}

\begin{abstract}
Today heritage sites not only preserve the memory of grandiose moments of history, but also include the darker ones, which were previously either preferably forgotten or went unrecognised. In Finnish history, it is difficult to find a more painful example of these "sites of pain and shame" than the 1918 Civil War. This article examines the different ways that the 1918 Finnish Civil War is commemorated and represented on the Internet today, on both private and institutional websites as well as in social media, from the perspective of participatory history culture and vernacular authority. People have always shared information concerning the past with each other, but the way that this can be observed on the Internet today is novel. Only after the rise of new technology, the Internet and especially Web 2.0, people have had the possibility to share their experiences and interpretations side by side with history professionals to this degree. In relation to memory and heritage politics, this means that we need to re-examine the boundaries between private and public memory and official and unofficial heritage, and recognise new forms of collaboration between audiences and institutions.
\end{abstract}

Keywords: digital memories, family history, 1918 Finnish Civil War, new heritage, online commemoration, participatory history culture, sites of memory, vernacular authority

\section{INTRODUCTION}

Today heritage sites not only flag the positive features of humanity, but also include "sites of pain and shame", heritage sites related to historic episodes, and events that most countries and people would rather forget about, such as wars and other acts of violence, prisons and mental asylums. This shift to preserve also the darker sides of human action is said to have sprung from different, even opposite needs to feel grief, gratitude, comfort, shame, fear, anger and, in the case of "dark tourism", also pleasure (Logan \& Reeves 2011: 1-4; see also Ashton \& Hamilton \& Searby 2012: 3). In Finnish history it is difficult to find a more painful example than the 1918 Civil War, which divided the people of Finland into two sides, the Reds and the Whites, for decades. The war that lasted less than four months led to the death of nearly 37,000 people, of whom the major- 
ity belonged to the defeated, the Reds ${ }^{1}$, and effected Finnish society on every level and in long-lasting ways, some of which can still be acknowledged today.

Elie Wiesel, a Nobel Prize winner, distinguished author and political activist, has stated: "The executioner always kills twice, the second time with silence" (cited in Logan \& Reeves 2011: 2). ${ }^{2}$ This was the situation also in Finland, where for decades after the Civil War official and public commemoration of the war dead applied only to the winners, the Whites, whereas the families of the Reds were declined the right to mourn or honour the memory of their dead in public, and were therefore forced to commemorate and process their losses in the private sphere. Over half a century had to pass until the silence was finally broken in the $1960 \mathrm{~s}$, and the experiences of the Reds were given public recognition (Heimo \& Peltonen 2006 [2003]). Nevertheless it took another twenty years until the political climate in Finland was ready for the state to embark on a project to gather information concerning all the victims of the 1918 Civil War for the first time. ${ }^{3}$ Today the situation is very different, and information concerning the Civil War can be accessed easily - especially if you have an Internet connection on hand.

This article is a follow-up of my recent study (Heimo 2010a) on narrated memories of the 1918 Finnish Civil War in one particular vicinity, from the perspective of the social process of history-making. This never-ending process of history-making comprises the interplay of public, popular and scholarly histories (Kalela 2013). History is, as social historian Raphael Samuel points out, a social form of knowledge, in which we all participate, regardless of our education, profession or motivation (Samuel 1994; see also Ashton \& Hamilton 2010: 7-8; Kean \& Ashton 2009: 1-6). In my study I focused on the relationship between public and local interpretations of the Civil War presented in various forms: academic history, films, novels, museums, school textbooks, memorials, documents, autobiographical materials, narrated family histories, and so forth. In my research I used digital sources, e.g., databases like the War Victims of Finland 1914-1922 and the Memorials of the Reds database of the Finnish Labour Museum Werstas (Työväen museo Werstas, Punaiset muistomerkit), as well as websites like vapaussota.fi (The War of Freedom). However, at the time, I regarded them as sources like any other, without giving any thought to their digital form.

After I had finished my study, I tumbled upon a family history published on a blog by a grandchild of a Red executed during the Civil War, and only then did I begin to realise the impact of the Internet in this process and especially what it meant in terms of former perceptions of private and public memories and the social process of history making (Heimo 2010b). In this blog, author and poet Kaija Olin-Arvola tells the story of her grandparents. Her grandfather 
Vihtori Lindell belonged to the Red Guard and was shot to death along with eleven other men in Nummi on 6 May 1918. In her story, Olin-Arvola recollects a family narrative about the last time that her grandparents saw each other. Before he was executed, Vihtori was taken to see his wife, Iitu, and the White guard said to her: "Take a good look now, Iitu, this is the last time you have seen Vihtori" (Olin-Arvola 12.4.2010). The story of the capture and execution of these men was well known and mentioned also by many of my interviewees, but this particular incident seems to have been shared mainly in a close family circle, because it was not mentioned by any of my respondents. Only after Olin-Arvola wrote it down, first for a family reunion and then published it on her blog, it entered the public sphere. Being an active debater, she has also later on referred to her grandfather's fate several times elsewhere; for example, on other blogs of hers and on several different discussion forums of Finnish newspapers (e.g., Olin-Arvola 31.3.2012; Olin-Arvola 11.11.2011; Olin-Arvola 15.10.2010; Olin-Arvola 19.12.2009). Even 90 years after the Civil War, her grandfather's tragic death continues to have a meaning for her. Besides the fact that her grandfather's fate is a significant part of her family history, the author uses it to express her political views.

\section{STUDYING PARTICIPATORY HISTORY CULTURE ON THE INTERNET}

In their highly influential study, Presence of the Past, Roy Rosenzweig and David Thelen (1998) call our everyday engagement in history participatory history culture. The ways that we engage in history-making have transformed substantially in the past ten years. Due to Web 2.0 technology, people are no longer passive spectators of historic events, but active participants in history-making. Other significant changes have also followed. Visual sources are replacing written ones and for many history has become a leisure pursuit (Tredinnick 2013).

In this article I explore public and private commemoration and historical representations of the 1918 Finnish Civil War on the Internet. I began my study by conducting a Google search in March 2013, and found to my surprise that the English search words "civil war 1918 finland" gave 2.1 million results, whereas the same search in Finnish, "sisällissota 1918 suomi", provided only 780,000 results. Amongst these hundreds of thousands of results, I investigate some ten Finnish websites most often mentioned on link lists of where to find further information on the Civil War, and additional examples of how the Civil War is commemorated privately and publicly in social media, in particular on Facebook, because out of all social media sites it was clearly the most popular one 
used for these purposes at the time of writing this article. Although I examine the peculiarities of online commemoration and history-making, I see no point in juxtaposing the "virtual" and the "real" world. In my view, the virtual is a part of our everyday social world and the Internet has been culturally adopted by the major part of Finnish society (Suominen 2013: 20).

Folklorists have been slow in recognising the impact of the Internet for vernacular communication and cultural expressions even if, as Trevor J. Blank points out in reference to the work of Jonas Larsen, John Urry and Kay Axhausen (2008):

[---] new media technology has become so ubiquitous and integrated into users' communication practices that it is now a viable instrument and conduit of folkloric transmission; it works reciprocally with oral tradition, offering digital renderings of familiar interactive dynamics that allows users to advantageously communicate across face-to-face and digital settings in equally meaningful ways. [---] One expressive venue is not separate from the other; users employ them cooperatively and interchangeably. (Blank 2012: 4)

Fortunately, the situation is gradually changing and folklorists have begun to show a growing interest in the numerous ways that folklore culture and vernacular expressions are mediated on the Internet (e.g., Blank 2012). Robert Howard (2013: 76, 82) stresses that it is important that folklorists in particular examine the construction and use of power relations, in other words, vernacular authority, in participatory media, where the institutional and vernacular often occur side by side. According to Howard, vernacular authority "emerges when an individual makes appeals that rely on trust specifically because they are not institutional". The appeal is backed up, for instance, by tradition and not by a formally instituted social formation like church, media company or an academic publication (ibid.: 81). In my article, claims are most often based on family history and postmemories.

However, because so few folklorists have yet touched upon online historymaking, memorialisation and commemoration, my article relies, to a large extent, on the work done by scholars of other fields, mainly oral history, memory studies, media studies and cultural heritage, and certainly also online ethnography.

Online ethnography is challenging in many ways. The Internet is dynamic by nature, which means that one's research topic is continuously on the move, websites and online communities are often founded with great enthusiasm and forgotten soon, online phenomena are born spontaneously in one instance and gone in another (see, e.g., Suominen 2009). Another essential issue is the ques- 
tion of private and public on the Internet. Many recent studies have shown that although an online forum or website might be open to all, the active users do not necessarily regard as public. Then there is also the question of third parties. Even if you have permission to study a specific site, do all those engaged in posting and commenting realise that they are being studied? (see, e.g., Markham \& Buchanan 2012) Many online ethnographers today argue that, as a method, mere non-participant observation (lurking) is not only insufficient, but also unethical (e.g., Miller 2012). However, because I examine memories published on public or semi-public sites clearly aimed at wider audiences that do not require registration, I have, in most cases, applied non-participant observation without announcing my presence as a researcher. Nevertheless, I have asked permission to use the material published on personal Facebook profiles, and also from Kaija Olin-Arvola mentioned above. Although her writings are all on public sites, in my analysis I have created her profile by connecting material published on different forums in a way that she has not anticipated.

\section{ONLINE PARTICIPATORY HISTORY CULTURE}

Oral historian Alistair Thomson stated already back in 2007 that we are currently in the middle of a fourth paradigm of oral history ${ }^{4}$, which he called the "digital revolution". According to Thomson, new digital technologies will radically transform the ways in which we record, preserve, catalogue, interpret, share and present oral histories, and as we today know, this has happened in more ways than one. While a decade ago oral historians were still quite cautious towards online interaction (e.g., Cohen 2013 [2005]), today many see the benefits of doing oral history online, and have gradually even begun to warm up to all the possibilities that blogs and social media sites such as Facebook, Twitter and YouTube offer. Now there are websites like Oral History in the Digital Age (OHDA), which promotes the use of digital technologies and guides the users how to record, archive and disseminate oral history projects online.

Besides online archives maintained by organisations and institutions, there are an increasing number of alternative attempts to offer the same services. One interesting example is Memoro: The Bank of Memories, which describes itself as "a no profit project available as an online archive in which the stories of memories and experiences of people born before 1950 are collected, classified and shared on the web by short videos/audio interviews". The project that began in 2007 has published thousands of interviews by people from over a dozen countries around the world. A similar Finnish example is Epooq, an award-winning Internet service founded in 2009 for the storing and sharing 
of (written) life stories and memories developed by a Finnish firm. ${ }^{5}$ Both of the projects state that they are particularly interested in the memories of the "older generation", "people born before 1950" and "grandparents". Although the potential of both projects is huge, it seems that neither of them has attracted as many users as they have the capacity to handle or as they have hoped for. This seems to be a common phenomenon for the sites designed to draw people to share their memories. Be they official or alternative, they usually do not attract people to collaborate as actively as those that are formed spontaneously by individuals with similar interests (Affleck \& Kvan 2008: 275) or shared experiences (Arthur 2009: 72).

One thing that Thomson - or anyone else for that matter - did not at the time predict and the OHDA website does not actually deal with, is the number of people "doing history" by themselves and for themselves and their peers on the Internet, and especially on social media sites. In less than a decade, social media has proven its multifaceted potential in sharing contents, building and maintaining relationships and generating conversations. Oral history is particularly characterised as "history from below", and the above examples represent quite opposite perceptions. They do not seem to acknowledge the fact that people are no longer mere users of the Internet, but are now producers, as Axel Bruns (2008) calls individuals who are engaged in the activity of both production and usage, in other words, produsage. Media scholar Henry Jenkins calls this creating and circulating of one's own work participatory culture. Participatory culture highlights community involvement, and welcomes all people to contribute, but does not require it. Participatory culture is not only about production and consumption; it is also about affiliation, expression, collaboration, distribution and the disclaiming of former divisions between professionals and amateurs (Jenkins et al. 2006).

Participatory culture and grassroots activities are also characteristics of digitally born new heritage. Heritage no longer consists of only museum artefacts, memorials or historic sites, but, as Elisa Giaccardi points out: "It is about making sense of our memories and developing a sense of identity through shared and repeated interactions with the tangible remains and lived traces of a common past" (Giaccardi 2012: 1-2). New technology enables users to participate spontaneously and continuously in curating new heritage (ibid.: 2 ; see also Kaplan 2013: 126-127).

Not all are pleased with this new development. In his article "Trust, Risk \& Public History", James Gardner portrays a somewhat pessimistic view on usergenerated material, which, according to him, is mostly a mere opinion and not original or creative work (Gardner 2010: 54-55). Perhaps it is my background 
in folklore studies that makes me unwilling to share the same concern as, for example, Gardner, about what happens when people begin to do history on the Internet and in social media. While it is true that most people are content just to passively follow other people's activities or share the contents created by others on the Internet, ${ }^{6}$ this does not mean that we should undermine the work of those who do contribute and participate in history-making on the Internet.

Although more people are now involved in the consuming, doing and making of history, it is a matter of debate to what degree this change will democratise history. Will the most significant purveyors of historical interpretations continue to be institutions, schools, museums and academia, as Paul Ashton and Paula Hamilton (2010: 7-8) suspect, or will the walls of institutional heritage organisations dissolve, as Graham Fairclough suggests (2012: xvi), and lead to the loss of all control, as James Gardner (2010) fears?

\section{FAMILY MATTERS}

Since the 1990s there has been a notable increase in family history research in many countries, and family history has become one of the most popular reasons for people to engage in participatory history culture (Rosenzweig \& Thelen 1998: 21-22, 89-114). This unprecedented turn has been explained in several ways. In addition to the importance for self-making, self-exploration and self-understanding, this emergent interest in one's own roots has been seen to spring from the need to personalise and democratise history (Ashton \& Hamilton 2010: 27-28; Kramer 2011). This turn can be well observed on the Internet (see Heimo 2014). It has never been as easy as today to access historical records in archives, both material and digital, or to discuss your mutual heritage with people who you might have met only virtually over the Internet. Because of the Internet, our essential desire "to understand who we are and where we come from is just a click away", as oral historians Katrina Srigley and Stacey Zembrzycki (2009) have put it.

In most Finnish families the Civil War has not been talked about openly. Only in the 1990s, after over 80 years of silence, people began to show an interest in the experiences of their relatives during the Civil War, and to share their family stories in public (Heimo 2010a: 134-136; see also Latvala 2005: 188-192; Torsti 2012: 123-126). The following letter published on the Fellman Field blog (Fellmanin pelto) offers a good example of how attitudes have changed over the years. The letter was written by a nephew to his great-aunt, who was executed in Lahti in 1918, at the age of 22, 95 years before. 


\section{Dear Great-Aunt,}

I am writing this letter 94 years after your death. It will not reach you, but I only found out about you a few years ago when I came across your name in the War Victims in Finland 1914-1922 database.

You have not really been discussed in the family, and later when I asked about you, the matter was avoided, dodged and romanticised. There is no reason for this even if the matter has been covered (and feared?) all these years. The war continued long after you were gone and encapsulated deeply.

93 years after your death, a study was written of your sisters-in-arms, or actually only about the ones who survived, though they ended up in jails and prison camps. In this book they only tell about the prison camp in Hämeenlinna, though there were others too [---] (Hongisto 6.4.2013).

He continues telling the story of his great-aunt, how he found her picture in the book mentioned above. Throughout his letter he refers to the studies he has read, court records and other sources, and imagines how she would have felt about the accusations directed at the losers of the war, the Reds, and especially women on the Reds' side. The blog-text neatly exemplifies the social process of history-making and how a private family narrative - or family secret - is made public and transformed into a larger narrative concerning the fate of the Reds, and especially the women on the Reds' side. It also displays how digital media has expanded the idea of "giving voice", by giving everyone equal opportunities to participate in history-making.

\section{MEDIATED MEMORIES AND ONLINE REMEMBERING}

In her study Mediated Memories in the Digital Age (2007) José van Dijck states that in our present culture where analog memory objects (photographs, diaries, etc.) are being substituted by digital objects, it is even more important than before to ask why and how memory matters. By mediated memories she means memory objects created by all kinds of media technologies, from pencils to smart phones, which mediate with our past and with all those with whom we have a relationship. Digital technologies do not only transform our notions of privacy and openness, but also demand us to view over again the relation between personal memory and lived experience (van Dijck 2007: xiv-xv, 1).

Digital memories come in numerous forms, but they have one common feature: they can be shared online. Joanne Garde-Hansen, Andrew Hoskins and Anna Reading name, amongst other things, the following as digital memories: 
Online mementos, photographs taken with digital cameras or camera phones, memorial web pages, digital shrines, text messages, digital archives (institutional and personal), online museums, online condolence message boards, virtual candles, souvenirs and memorabilia traded on eBay, social networking and alumni websites, digital television news broadcasts of major events, broadcaster websites of archival material, blogs, digital storytelling, passwords, computer games based on past wars, fan sites and digital scrapbooks. ${ }^{7}$ (Garde-Hansen \& Hoskins \& Reading 2009: 4)

Although the list of examples is infinite, all of these examples fulfil an age-old function, the need to "control time, recollection, grief and trauma" and deal like all memories do with the past's relationship to the present (ibid.).

It has been stated that new technology has created an "archive fever" (see Derrida 1995), a powerful urge to keep track, record, retrieve, archive, back up and save, more intense than ever before. However, this attempt to save "everything" has also been criticised (Garde-Hansen \& Hoskins \& Reading 2009: 5). Will the saving of "everything" affect the natural processes of forgetting? Will we end up in a situation in which the default of human societies will be remembering rather than forgetting? Would it actually be more merciful for all of us if "everything" was not remembered, but some things were also forgotten? Will only purified versions of the past be saved?

Many cherish as their dearest heirloom their own private archives, photographs, letters, cards, diaries, clippings, drawings, and so forth, of their close family members and ancestors. In addition to feverish archiving, many have been surprised how willingly and how many people actually want to share their private memories in public now that it is technically possible. With our smart phones and tablet computers we can now share our child's first steps, family holidays and other memorable moments the instant they take place. Before the digital age, these shots were rarely shared outside the family circle. While some fear that this affects the level of our privacy and in time will lead to the deprivation of our privacy (Maj \& Riha 2009: 1-3), others see that people's attitudes to what is regarded as private in the first place have changed (Hoskins 2009). This change also means that digital memories are open to continuous remediation, reformulation, reformatting, recycling and remixing, to the extent that it has been suggested that there is no longer need to talk about private and public memories (or personal and collective memories) as separate categories (e.g., Garde-Hansen \& Hoskins \& Reading 2009: 6, 14). It also challenges our conventional perceptions of archived memory as fixed and stored, and has, according to Andrew Hoskins (2009), resulted in the birth of a new memory, 
a digital network memory, or living archival memory subject to be added to, altered or erased.

Through the social web we document our life continuously for more or less public audiences. This documenting is performative, because it involves selecting what, in which way and with whom we share our memories. In memory studies this has led to the increase of focusing on the active processes of remembering and commemoration instead of memory or memories as static products (see, e.g., De Bruyn 2011: 82).

\section{ONLINE COMMEMORATION}

In the latter half of the 20th century, a culture of commemoration emerged in western societies. More and more people want to take part in commemorative acts and in this way connect with the past (Ashton \& Hamilton \& Searby 2012: 1). Instead of taking part in organisationally or institutionally organised acts of memorialisation, people seem to have a growing need to act individually on the personal level. Spontaneous, grassroots, and vernacular memorials spring up at sites of untimely and unexpected deaths. Private memorials exemplify individualised political participation and social action, and are a sign of the subjective turn of postmodernity (Margry \& Sánchez-Carretero 2011: 1-4, 28-29; Ashton \& Hamilton \& Searby 2012: 7-8). Another feature of this new culture of commemoration is retrospective commemoration, the commemoration of events or deaths, which were, deliberately or non-deliberately, not noted down when they happened (Ashton \& Hamilton \& Searby 2012: 9).

All of these shifts can also be easily perceived on the Internet, which is full of both large institutional and small-scale private sites of memory and commemoration. The capacity to present various and conflicting stories in one place is one of the assets of online environments, and especially social media offers a means to create multivoicedness and dialogism, which is difficult to achieve in conventional museum exhibitions or at memorials (Arthur 2009; De Bruyn 2010). Online websites draw likeminded people together by offering support and a chance to give testimony and to be heard. In time these commemoration sites have a possibility to transform from initial impressions and testimony into online archives (Arthur 2009). In times of trauma, crisis, grief and mourning, these have been seen to offer a "comfort culture", which allows us, "tourists of history", immediate access to the sites of memory (Sturken 2007: 6-7).

Although most online commemoration is spontaneous and focuses on current tragedies, social media sites are used increasingly to also commemorate painful historic events retrospectively and share postmemories of these with transnational audiences ${ }^{8}$ (Arthur 2009; De Bruyn 2010). 
Even though most of these sites focus on the commemoration of specific events, there are also websites like the Information Portal to European Sites of Remembrance, which brings together and presents memorials and museums dedicated particularly to the memory of the Holocaust, but also other victims of National Socialist crimes and the Second World War around Europe. Another example of a similar project is the Polynational War Memorial funded by the Swedish Arts Grants Committee. The project began in 2004 and was planned to gather the names of more than ten million soldiers and civilians, and a database of online and offline war memorials situated around the world. Nearly ten years later it has gathered only 348,000 names on its site and mentions, for instance, only two Finnish war memorials. These types of sites are usually created for pedagogical, ethical or political reasons, but not for therapeutic reasons like the ones that commemorate contemporary tragedies. This also means that, because people do not have an urgent need to use these sites, their effectiveness relies on their distribution, circulation, and performativity within the public; yet, as mentioned earlier, it is not easy to attract users to participate actively.

Since the First World War, war memorials have been a familiar sight all around Europe (Winter 2003: 79) as well as elsewhere (Ashton \& Hamilton \& Searby 2012: 4). War memorials are common reminders of bygone violent conflicts, lost lives and suffering; yet, they leave personal and individual tragedies untouched. According to Paul Arthur, war memorials are usually so well integrated into the grand narrative of a nation that they have the power to unify, even in the case that they are only general and representative (Arthur 2009: 65-66). However, this does not apply to all cases. After the 1918 Finnish Civil War, only the Whites were allowed to erect memorials to grieve their losses and to honour their heroes, and were publically acknowledged. All in all, there are approximately 330 memorials commemorating the Whites and 150 the Reds, and only three that commemorate both sides. Nearly all of the White memorials were erected during the $1920 \mathrm{~s}$, whereas monuments in memory of the Reds became more common only after the Second World War and some have been erected as recently as in the 2000s (Peltonen 2003: 221-236).

To achieve more visibility for the memorials of the Reds, the Finnish Labour Museum Werstas founded a database for them. The Red Memorials in Finland database consists of photographs and basic information concerning memorials from all over Finland. An interesting feature is that all the photographs have been digitally manipulated so that all the names engraved on the memorials are unreadable. This is to ensure the privacy of the dead, which in this case the Data Protection Ombudsman has regarded important, because the memorials are considered politically sensitive even today. Yet, similar pictures of the same memorials and graves have been published on other sites with the names in sight. 


\section{(WEB-)SITES OF MEMORY}

Finland has dozens of museums with exhibitions on war history, but most of these are related to the Second World War, the Winter War or the Continuation War. ${ }^{9}$ The first attempt to establish a museum focusing solely on the Civil War is still under consideration. ${ }^{10}$ The situation is not much better on the Internet either. In his study on over 100 Finnish online museum exhibitions, Kalle Kallio (2005: 101) noted that the Civil War, like many other difficult historic events, has been overlooked. Since then, the situation has somewhat changed, because in 2008 several museums and archives commemorated the 90th anniversary of the Civil War with new exhibitions (see Museot.fi 23.4.2008). Nearly all of these were on-site exhibitions, but some were also partly or solely published on the Internet, where they can still be found. The majority of these online exhibitions are quite simple, and consist primarily of texts (articles) and in some cases also photographs of digitised documents, but do not utilise sound, video or other forms of media. ${ }^{11}$

The winners of the war, the Whites, are honoured and commemorated on numerous websites maintained by organisations committed to the War of Freedom, the White Civil Guard and its equivalent organisation for women, Lotta Svärd ${ }^{12}$, and the Commander-in-Chief of the War of Freedom, Carl Gustaf Emil Mannerheim ${ }^{13}$. The chief website commemorating the Whites is Vapaussota.fi, which is maintained by the Vapaussodan Invalidien Muistosäätiö (Union for the Commemoration of Disabled Veterans of the War of Freedom). On the site one can find, among other things, information and maps of the most significant battles, songs, literature, original footage and the multimedia mentioned below. Vapaussodan perinneliitto (The Tradition Union of the War of Freedom) also has a website of its own, Perinneliitto.fi, which presents the more than thirty local associations around Finland. In addition to offering information about these associations and current events, these websites present the history of the Civil War from the perspective of the winners, which means that they do not mention the harsh aftermath of the war. This also applies to a multimedia Vapaussota 1918: Kapina, sisällissota, kansalaissota (War of Freedom 1918: Rebellion, Civil War, People's War) published in 2008 to commemorate the 90th anniversary of the war. The multimedia mentions that thousands of people died as a result of the war, but does not give any explanations for the casualties, which is in line with the dominant White interpretation of the war (see Heimo \& Peltonen 2006 [2003]). Perhaps as a kind of compensation, the title of the multimedia features the different names of the war used by the different sides..$^{14}$ It also presents some commanders of the Red Guard and uses archive materials from the People's Archive and other collections of the Red side. 
The Red side does not have similar websites to commemorate their legacy. For long the last official organisation for the Reds, Entisten punaisten jälkeläisten keskusjärjestö ry (The Descendants of Former Reds) was disbanded in the 1980s. The Communist Party in Finland and numerous local workers' organisations have taken the role of commemorator for the Reds, but do not have specific websites for this. In 2010 a new association was established, the Suomen Työväen Järjestyskaartin Perinneyhdistys ry (The Tradition Association of the Finnish Workers' Guard) to commemorate and narrate the history of those who lost their lives on the Red side in the Civil War. The association has only a Facebook page (see below).

The situation is the same on Facebook. The commemoration of the civil war seems to attract more people dedicated to the legacy of the Whites than to that of the Reds. In spring 2013 the Facebook group Suojeluskunta (Skyddskår) järjestön muistolle (Legacy of the White Civil Guard) was an open group. It had only some 40 members (as of 5.4.2013), but was quite active. Most of the postings concerned the sharing of the history of the White Civil Guard, links to TV-documents, museum exhibitions, photos, etc. Since then the group has changed from open to closed and the number of members has tripled to 133 (as of 12.12.2013). The two most popular pages, Baron Carl Gustav Emil von Mannerheim and Mannerheim, are both dedicated to the memory of the leader of the White army, Field Marshal Mannerheim, and resemble, to a certain extent, fan pages. Both of the pages have over two thousand likers from all over the world, but are not very active. The former page is transnational with comments in three languages: English, Swedish and Finnish. The latter is in Finnish, but seems to attract people to participate mainly on the Independence Day of Finland, December 6.

At the moment there are only two Facebook pages commemorating the Reds. The Facebook page of the Tradition Association of the Finnish Workers' Guard has 253 likers. The page was created in 2011 and was quite active until February 2013, but for some reason there have been very few postings after this, though the page has gathered some more new likers since spring (as of 26.3.2013 \& 16.12.2013). On KIITOS 1918 (Thank you 1918) over 440 people have wished to demonstrate their gratitude to the Reds by liking the page, but for some reason have not shown any need to post on the page. A year ago there were several more pages for the Reds, for instance, a group for the descendants of Red prisoners of war (Punavankien perilliset) and another for the memory of the Reds (Punakaartilaisen muistolle), but, like so many other groups on Facebook, they have withered and then been deactivated. Whereas the Suomen Työväen Järjestyskaartin Perinneyhdistys ry page is dedicated mainly to the history of the Civil War, the two latter ones attracted people to share their postmemories. 
The most active Facebook page at the time of writing this article is the Fellmanin pelto - 22000 ihmisen elävä monumentti (Fellman Field: A Living Monument to 22,000 People) with 1,866 likers (as of 3.5.2013). On April 28, 2013, artist Kaisa Salmi organised a large-scale participatory performance "Fellman Field: A Living Monument to 22,000 People" in Lahti at the same place where 22,000 Reds waited for six days to be sentenced in April-May 1918. In addition to following the preparation of the event, people were eager to express their thoughts about the performance. Many of the participants were grandchildren of the original prisoners and wished to commemorate them by participating in the living monument and sharing their grandparents' stories on Facebook. Some announced that they were grandchildren of the Whites, and wanted to amend their grandparents' doings. After the performance was announced as part of the Commemoration of Reds in Lahti 1918 events arranged by several local workers' organisations, some people were offended that, instead of reconciliation, the barrier between the Reds and Whites was once again strengthened, and so they withdrew their participation.

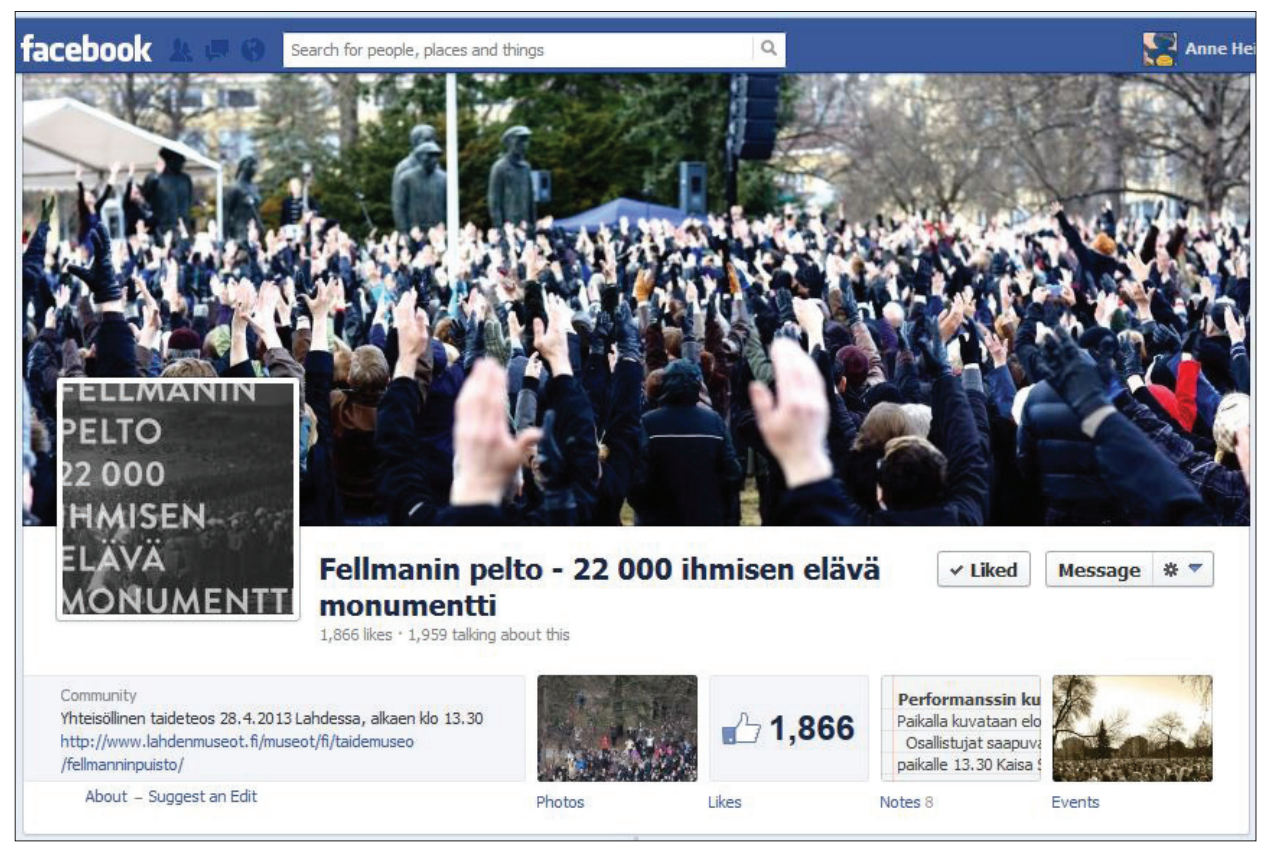

Figure 1. The Facebook page of the Fellman Field performance. Screenshot 3.5.2013. 


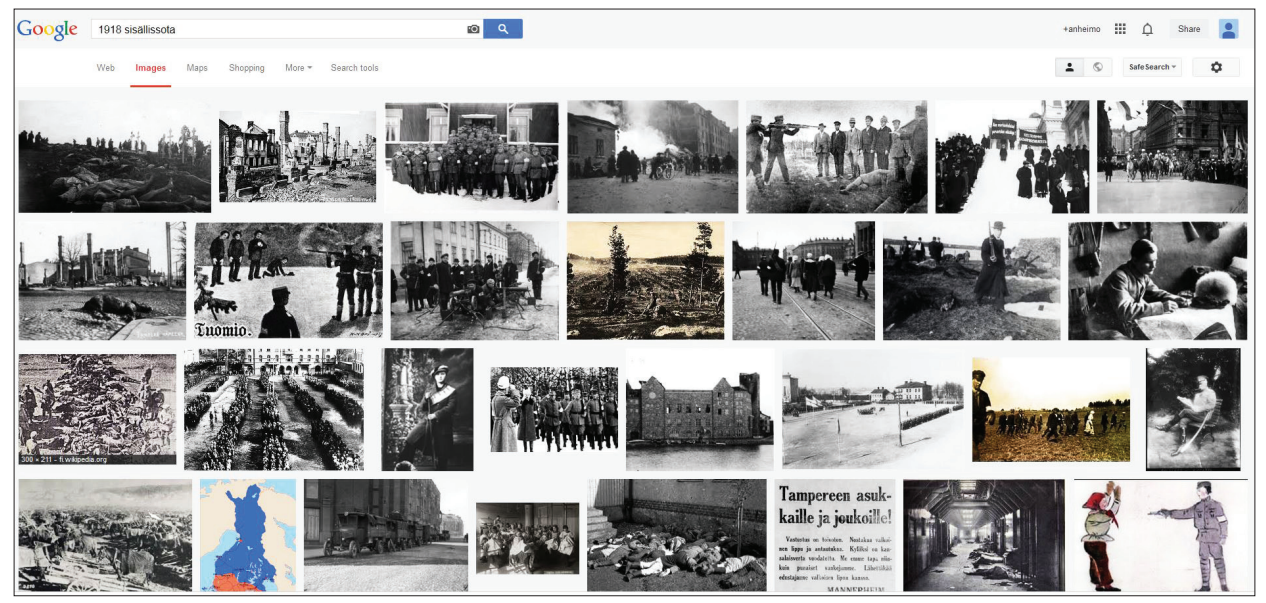

Figure 2. Images of the 1918 Finnish Civil War. Screenshot 7.1.2014.

The performance also has its own blog, Fellmanin pelto (Fellman Field), on the website of a local newspaper, Etelä-Suomen Sanomat (South-West Finland News). In the blog, more or less known figures, who had participated in the performance, reflected on their thoughts about it, as well as about the Civil War and other atrocities. All of the 15 blog texts have been shared (from 4 to 285 shares), but only a few have been commented on. ${ }^{15}$

Visuality is an increasing feature of all social media, and digitised photos and videos uploaded and shared on Facebook, Flickr ${ }^{16}$ and YouTube will, in the course of time, challenge the hegemony of written historical records (Tredinnick 2013) and authorised heritage discourse (AHD) (Pietrobruno 2013; see also Latvala in this volume). The visual image of the Civil War has been dominated by pictures of men lined up to be executed, poorly dressed and armed soldiers of the Red side and Mannerheim leading the parade of the winners of the Civil War in Helsinki on May 16, 1918. Although YouTube lacks some features commonly associated with archives, it still gives access to user-generated materials as well as various types of materials originating from archives, television and concert recordings (Brunow 2013: 11-13). Civil War related video clips on YouTube ${ }^{17}$ include original footage and photos, movie trailers, oral history interviews, videos of historical re-enactments and visits to battle or memory sites, as well as songs. The most popular ones have been viewed tens of thousands of times. The most popular YouTube video consists of a single photo of an execution site. On the soundtrack a labour-movement singer Heli Keinonen 
sings the song "Kuolemaantuomitun hyvästijättö" (Farewell of a Person Condemned to Death). Although the video is very simple, it still has the power of touching people. It has been viewed 148,356 times and has been commented on 174 times since it was uploaded in 2008. Although most of the comments present personal views, some very pronounced, some people have also shared their family stories in the comments.

\section{SPONTANEOUS REACTIONS AND VERNACULAR AUTHORITY}

Every now and then the Civil War still provokes discussions or more or less heated debates on discussion forums and social media sites. ${ }^{18}$ This year topics like "Tammisunnuntai", the date of the beginning of the Civil War, 27 January, historian Tuomas Hoppu's new book Vallatkaa Helsinki (2013) about the conquering of Helsinki by the Whites with the help of German troops in March 1918, the 95th anniversary of the battle of Tampere in March-April, and the vandalising of Mannerheim's statue in Tampere in November stimulated spontaneous discussions on both public and private forums. All of these topics have also prompted spontaneous reactions on Facebook. The following examples from my own news feed present how the Civil War was discussed via social media in ordinary everyday situations.

On 25 January 2013, Marko Korvela, the editor in chief of the online version of the weekly newspaper Tiedonantaja (The Informant), the chief organ of the Finnish Communist Party, noted on his personal Facebook profile that while his newspaper uses the terms 'working class revolution' and 'class war', the main newspaper of the Left Alliance, Kansan Uutiset (People's News) refers to the war as the Civil War. In just two days 13 people sent 38 comments about the topic. While some of the commenters felt that it was time to use neutral names like the Civil War or the War of 1918, some thought that it was important to use names that illustrate the ideology of the war, and stressed that they could never refer to the war as the War of Freedom like those siding with the winners of the war do even today. One commenter presumed that it might be difficult to use neutral terms if some of your family members were killed in the war, and referred to an online article published in a local parish newspaper about mass graves of the Reds in Hämeenlinna. Alongside the discussion about the name of the war, some of the commenters also linked to different websites to stress their point. For instance, one person referred to an article discussing the different names of the war, which was republished on a website on Tampere history, maintained by the History Department of the University of Tampere (http://www15.uta.fi/koskivoimaa/valta/1918-40/totuudet.htm ). ${ }^{19}$ 
Figure 3. The People's Archive posted an advertisment about the Commemoration Weekend of the Reds in Lahti in 1918 on its Facebook page on 24.4.2013. Screenshot 25.4.2013.

In April another Facebook friend of mine, a colleague born in the late 1950 s, wonders how the Civil War seems to come nearer and nearer as time passes by. The post received over 20 likes and several responses, which varied from humorous to serious comments on the commenters' relationships to previous wars. The first response comments on the different names of the war

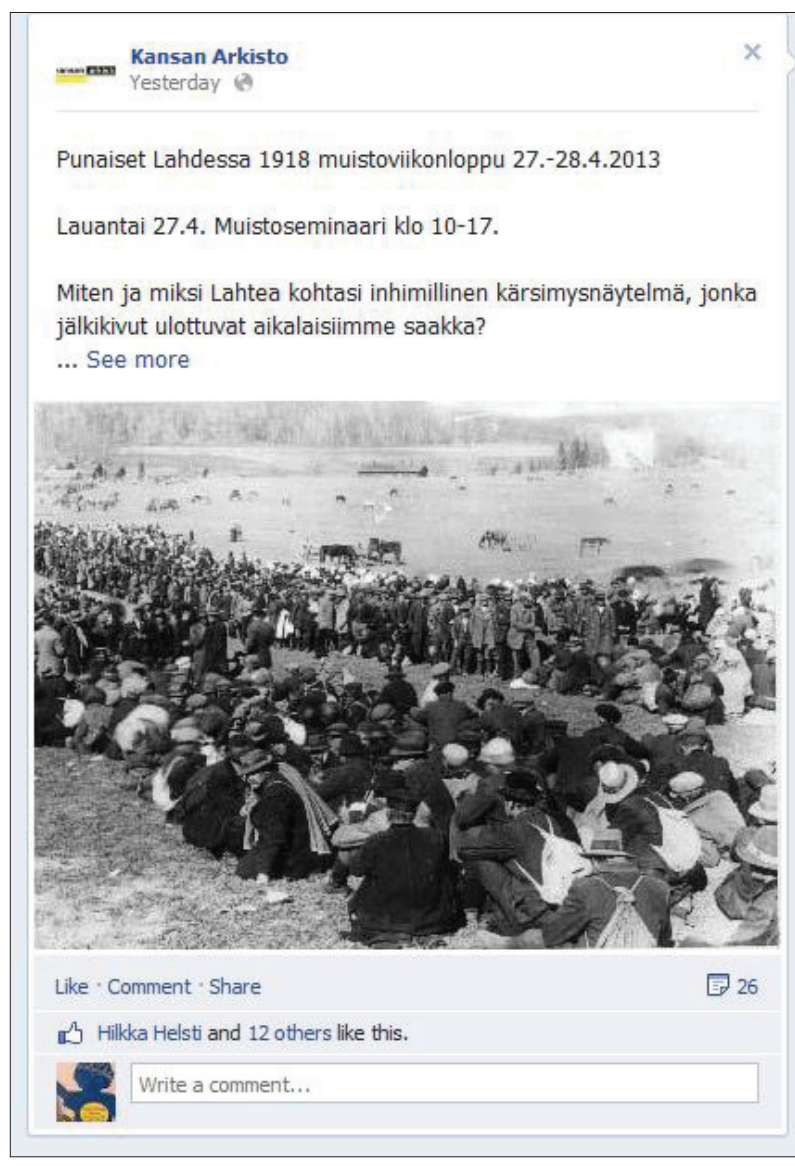

and how these express its different characters. It also mentions the bloodiness of the war. In the last comment the commenter mentions how the war was not talked about and that the study by Finnish historian Heikki Ylikangas, Tie Tampereelle (The Road to Tampere), published in 1993, finally ended the silence.

Later, the same month, the same colleague shared a post sent by Kansan Arkisto (People's Archive) (Figure 2) about a weekend event that commemorated the Reds in Lahti in 1918, which consisted of a seminar, concert and the Fellman Field performance mentioned above. Her post was liked seven times, shared twice and commented upon five times..$^{20}$ The comments are mostly about the need to remember. This time the commenters do not refer to institutional formations, such as studies, newspaper articles or websites. Instead, they express vernacular authority by bringing up their own personal connections to the events in Lahti and the Civil War in general. Several of the commenters mention that they have relatives who were prisoned during the war. The owner of the profile clearly acknowledges the fact that the discussion is happening on 
Facebook, and comments on the painful postmemories: "This cannot be liked". Nevertheless, all the other comments are liked by the other participants and no one wants to challenge them. The postmemories are regarded trustworthy and therefore deserve expressions of empathy.

\section{CONCLUSIONS}

Today, in the digital age, Raphael Samuel's idea of "everyone a historian" (1994) has materialised in ways that he himself could not have imagined at the time. Although people have always taken part in the social process of history making, only after the rise of new technology, the Internet, and especially Web 2.0, have people had the possibility to share their experiences and interpretations side by side with history professionals to this degree. The Internet, and especially social media, has also altered and transformed former understandings of cultural heritage, and this means that we need to re-examine the boundaries between private and public memories and official and unofficial heritage, and recognise new forms of collaboration between audiences and institutions (Giaccardi 2012: 4-5).

The focus of my article is on online memorialisation and commemoration of the 1918 Finnish Civil War, but I do not suggest that this commemoration is either common or well-known. On the contrary, it is quite scarce and fragmental. Whereas only a decade ago museums, archives and other heritage organisations still hesitated to handle the Civil War altogether, some have dealt with the topic in recent years, but it is still clearly overlooked, especially as compared to the Second World War.

My analysis indicates that people do not easily grasp at the opportunities to collaborate and interact, offered to them by different official and unofficial organisations. Most of the websites related to the Finnish Civil War that I have examined in this article were created to commemorate the 90th anniversary of the Civil War in 2008, and the oldest ones are from the late 1990s. The websites have very few interactive functions and the majority are not actively updated. And even the ones that are, seem to be more dedicated to the official commemoration and maintenance of the heritage of their organisations, than to discussing politics or ideology or collaborating with the public in any way. The most interesting and touching examples that I found were either spontaneous reactions to ongoing discussions or events, or family memories fuelled by the need to pass on family history and to participate in history-making. All these possess the performative effectiveness required for memories to be 
shared and reacted on, and also signify vernacular authority so sound that it is rarely undermined.

The Internet and social media provide opportunities for people to participate in the producing of heritage on their own terms, to the point that the question of where heritage production should take place has to be raised. Does it have to be in a museum or in a similar context controlled by experts and only encountered occasionally on visits? Or could heritage be a part of our everyday life in which we all participate (Fairclough 2012: xvi)? It is easy to predict that in 2018 the Civil War will be commemorated in a plenitude of ways, offline and online. It will be interesting to see what is the situation of online commemoration and heritage production then. Will by then museums and other organisations have found new means to collaborate with the public or will participatory history-making and personal memorialisation have grown even stronger than they are today?

\section{ACKNOWLEDGMENTS}

The preparation of the article was supported by the Academy of Finland (grant No. 250307) and by the European Cooperation between Science and Technology (COST) action "In Search of Transcultural Memory in Europe" (IS1203).

\section{NOTES}

1 Over 7,000 Reds were executed and nearly 12,000 died in prison camps. In addition, 70,000 Reds were accused of crimes against the state, condemned to imprisonment and deprived of their civil rights for years to come (see War Victims in Finland 1914-1922).

2 There are several slightly different versions of this citation circulating.

3 The War Victims in Finland 1914-1922 project conducted by the Prime Minister's Office (1998-2003) compiled a register of all those killed in the war. In addition to the register, the project has produced a dozen or so studies on the casualties of the civil war (Westerlund 2004). A database based on the register was published on the Internet in 2002, and it has become one of the most popular sources to find information about individual victims. Victims can be searched by name, date of birth, occupation, place of census registration, place of residence, place of death, and cause of death.

4 The three other paradigmatic revolutions in theory and method that Thomson (2007) mentions are: 1) the postwar renaissance of memory as a source for 'people's history'; 2 ) the development, from the late 1970s, of 'postpositivist' approaches to memory and subjectivity; 3 ) a transformation in perceptions about the role of the oral historian as interviewer and analyst from the late 1980s onward. 
5 Epooq.net was awarded the World Summit Award (WSA) in 2011 in the category of e-Inclusion and participation (http://www.wsis-award.org/winner/epooq-80020110609).

6 "In most online communities, $90 \%$ of users are lurkers who never contribute, $9 \%$ of users contribute a little, and $1 \%$ of users account for almost all the action." (Nielsen 2006)

7 Memories of the Civil War appear in all these forms. One interesting form that is not mentioned here is geocaching. The bookmark list Suomen sisällissota 1918 (Finnish Civil War 1918) mentions 19 different geocaching locations all related to the Civil War.

8 According to De Bruyn (2010: 49), online commemoration flourishes particularly in post-communist countries.

9 In addition to the military museum of the Finnish Defence Forces, there are 10 museums specialised in military history, and over 80 other museums about wars or with war history collections and exhibitions in Finland (see www.puolustusvoimat. fi; www.veteraaniperinne.fi).

${ }^{10}$ In 2010 the Suomen sisällissotamuseoyhdistys (The Finnish Civil War Association) began to plan the establishing of a museum in Mänttä-Vilppula, but it seems that the plans have since been discontinued (http://www.sisallissotamuseo.fi/).

${ }^{11}$ See, e.g., Tampere 1918 (Vapriikki Museum Centre, city of Tampere), Varkaus ja vuosi 1918 (Varkaus and the Year 1918, Museum of Varkaus), Vaiettu vuosi 1918. Näkökulmia sisällissotaan (The Silenced Year 1918. Perspectives into the Civil War, Nautelankoski Museum, Lieto), 1918 - Kansalaissota asiakirjojen kertomana (1918 The Civil War Presented in Documents, National Archives) and 1918 Kansalaissodan kuvia (1918 Photographs of the Civil War, People's Archive). The database Arjenhistoria. $f i$ (Everyday history) consists of the digitised collections of nine different museums and archives. The search word "war 1918" gives over 4000 hits, among them pictures of memorabilia, spoons and pieces of dried bread, brought back from prison camps by survivors after the war.

12 The Lotta Svärd organisation was founded only after the Civil War and is usually related to WW2. The Lotta Svärd Foundation supports former members of the organisation and is committed to maintaining nationalistic values and Lotta Svärd heritage. It has a current membership of 240,000 (http://www.lottasaatio.fi/).

${ }^{13}$ Mannerheim began his military career as an officer in the Russian army, but later not only became the military leader of the Whites in the Finnish Civil War, but also the Commander-in-Chief of Finland's Defence Forces during WWII, Marshal of Finland, and President of Finland (1944-1946).

14 'War of Freedom' is still in use by those who see the war as a war against socialism and for independence. After the war, the Red side referred to the war by different names, such as Rebellion, Class War, War of Brothers or People's War. Since the 1990s, the war has usually been referred to as the Civil War or the War of 1918 (see Historiallinen Aikakauskirja 2/1993).

${ }^{15}$ One of the bloodiest battles of the Civil War was re-enacted in April 2008, 90 years after the war. The Day in Tampere 1918 project involved numerous organisations, as- 
sociations and individuals. Its website serves as a kind of archive and is not updated. In addition to information related to this and other similar events, the website also published a plea to people to write about their postmemories, stories they had heard, or to reflect on their feelings about the Civil War, but only 11 people responded to the plea (http://tampere1918.blogspot.fi/).

${ }^{16}$ On Flickr the search words (in English) "1918 civil war finland" give 292 results, whereas the same words in Finnish receive only 55 hits. This seems to indicate the transnational character of Flickr. Most of the photos are from the re-enactment of A Day in Tampere 1918, or from sites and memorials concerning the Civil War and historical photos.

${ }^{17}$ On YouTube the Finnish search words "1918 civil war" gave 174 results, "1918 war of freedom" 189 results, "1918 whites" 304 and "1918 reds" 127. In English the results were higher: "1918 civil war" 390 and "1918 finnish civil war" 501 (last accessed on April 6, 2013).

${ }^{17}$ E.g., since 2004 the Civil War has been dealt with in some 950 discussions (search words "1918 sota suomi”) on Finland's most popular discussion forum Suomi24.fi.

19 The original article or actually a series of articles was published in Historiallinen Aikakauskirja 2/1993.

20 The original post on the profile of The People's Archive has been liked 17 times and shared 28 times, but not commented on (as of 12.12.2013). I find it interesting that none of the Facebook pages committed to the legacy of the Reds or the Whites reacted to the commemoration weekend in Lahti, though all the happenings, and especially the Fellman Field performance, were widely covered by the media.

\section{REFERENCES}

Affleck, Janis \& Kvan, Thomas 2008. Memory Capsules: Discursive Interpretation of Cultural Heritage through New Media. In: Y. E. Kalay \& T. Kvan \& J. Affleck (eds.) New Heritage. New Media and Cultural Heritage. Oxon: Routledge, pp. 92-111.

Arthur, Paul 2009. Trauma Online: Public Exposure of Personal Grief and Suffering. Traumatology, Vol. 15, No. 4, pp. 65-75. http://dx.doi.org/10.1177/1534765609350781.

Ashton, Paul \& Hamilton, Paula 2010. History at the Crossroads: Australians and the Past. Sydney: Halstead Press.

Ashton, Paul \& Hamilton, Paula \& Searby, Rose 2012. Places of the Heart. Memorials in Australia. Melbourne: Australian Scholarly Publishing.

Blank, Trevor J. 2012. Introduction: Pattern in the Virtual Folk Culture of ComputerMediated Communication. In: T. J. Blank (ed.) Folk Culture in the Digital Age: The Emergent Dynamics of Human Interaction. Logan, UT: Utah State University Press, pp. 1-24.

Brunow, Dagmar 2013. Rethinking Remediation and Reworking the Archive: Transcultural Reappropriations of Documentary Images of Migration. In: In Search of Transcultural Memory in Europe. ISTME Working Paper No. 2/2013. Available at http://transculturalmemoryineurope.net/Publications/Rethinking- 
Remediation-and-Reworking-The-Archive-Transcultural-Reappropriations-ofDocumentary-Images-of-Migration, last accessed on February 4, 2014.

Bruns, Axel 2008. Blogs, Wikipedia, Second Life, and Beyond: From Production to Produsage. New York: Peter Lang.

Cohen, Daniel J. 2013 [2005: available at http://www.dancohen.org/files/future_of_ preserving_the_past.pdf, last accessed on February 4, 2104.]. The Future of Preserving the Past. In: H. Kean \& P. Martin (eds.) The Public History Reader. London \& New York: Routledge, pp. 214-224.

De Bruyn, Dieter 2010. World War 2.0: Commemorating War and Holocaust in Poland through Facebook. Digital Icons: Studies in Russian, Eurasian and Central European New Media, No. 4, pp. 45-62. Available at http://www.digitalicons. org/issue04/files/2010/11/De-Bruyn-4.3.pdf, last accessed on February 4, 2013.

De Bruyn, Dieter 2011. From World War 2 to World War 2.0: Commemorating War and Holocaust in Poland on the Internet. In: P. Wilson \& P. McEntaggart (eds.) Navigating Landscapes of Mediated Memory. Oxford: Inter-Disciplinary Press, pp. 81-89. Available at https://biblio.ugent.be/publication/2066701, last accessed on March 12, 2014.

Derrida, Jacques 1995. Archive Fever. A Freudian Impression. Translated by Eric Prenowitz. Chicago \& London: The University of Chicago Press.

Fairclough, Graham 2012. Others: A Prologue. In: E. Giaccardi (ed.) Heritage and Social Media: Understanding Heritage in a Participatory Culture. London \& New York: Routledge, pp. xiv-xvii.

Garde-Hansen, Joanne \& Hoskins, Andrew \& Reading, Anna 2009. Introduction. In: J. Garde-Hansen \& A. Hoskins \& A. Reading (eds.) Save As... Digital Memories. London \& New York: Palgrave Macmillan, pp. 1-26.

Gardner, James 2010. Trust, Risk and Public History: A View from the United States. Public History Review, Vol. 17, pp. 52-61. Available at http://epress.lib.uts.edu. au/journals/index.php/phrj/article/view/1852, last accessed on February 4, 2014.

Giaccardi, Elisa 2012. Introduction: Reframing Heritage in Participatory Culture. In: E. Giaccardi (ed.) Heritage and Social Media: Understanding Heritage in a Participatory Culture. London \& New York: Routledge, pp. 1-10.

Heimo, Anne 2010a. Kapina Sammatissa. Vuoden 1918 paikalliset tulkinnat osana historian yhteiskunnallisen rakentamisen prosessia. [Rebellion in Sammatti: Local Interpretations of the 1918 Finnish Civil War as Part of the Social Process of History Making.] Helsinki: Suomalaisen Kirjallisuuden Seura.

Heimo, Anne 2010b. Kapina Sammatissa. Vuoden 1918 paikalliset tulkinnat osana historian yhteiskunnallisen rakentamisen prosessia. [Rebellion in Sammatti: Local Interpretations of the 1918 Finnish Civil War as Part of the Social Process of History Making.] Lectio praecursoria. Elore, Vol. 17, No. 2, pp. 138-143. Available at http://www.elore.fi/arkisto/2_10/heimo_2_10.pdf, last accessed on February 4, 2014.

Heimo, Anne 2014. Pereajalugu internetiajastul: diasporaa-genealoogia ja jätkuv ajalookirjutusprotsess. [Family History in the Digital Age: Diasporic Genealogy and Participatory History Culture.] Mäetagused: Hüperajakiri, Vol. 56, pp. 155-180. doi: 10.7592/MT2014.56.heimo. 
Heimo, Anne \& Peltonen, Ulla-Maija 2006 [2003]. Memories and Histories, Public and Private: After the Finnish Civil War. In: K. Hodgkin \& S. Radstone (eds.) Memory, History, Nation: Contested Pasts. Studies in Memory and Narrative. New Brunswick, NJ: Transaction Publishers, pp. 42-56.

Historiallinen Aikakauskirja 2/1993. Available at http://pro.tsv.fi/haik/index.htm, http:// www15.uta.fi/koskivoimaa/valta/1918-40/totuudet.htm, last accessed on March $12,2014$.

Hoppu, Tuomas 2013. Vallatkaa Helsinki: Saksan hyökkäys punaiseen pääkaupunkiin 1918. [Seize Helsinki: The German Attack of the Red Capital in 1918.] Helsinki: Gummerus.

Hoskins, Andrew 2009. Digital Network Memory. In: A. Erll \& A. Rigney (eds.) Mediation, Remediation, and the Dynamics of Cultural Memory. Berlin: de Gruyter, pp. 91-106.

Howard, Robert Glenn 2013. Vernacular Authority: Critically Engaging “Tradition”. In: T. J. Blank \& R. G. Howard (eds.) Tradition in the Twenty-First Century. Locating the Role of the Past in the Present. Logan: Utah State University Press, pp. 72-99.

Jenkins, Henry \& Purushotma, Ravi \& Clinton, Katherine \& Weigel, Margaret \& Robison, Alice J. 2006. Confronting the Challenges of Participatory Culture: Media Education for the 21st Century. Chicago: The MacArthur Foundation. Available at http://www.newmedialiteracies.org/wp-content/uploads/pdfs/NMLWhitePaper. pdf, last accessed on February 5, 2014.

Kalela, Jorma 2013. Making History: The Historian and Uses of the Past. In: H. Kean \& P. Martin (eds.) The Public History Reader. London \& New York: Routledge, pp. 104-128.

Kallio, Kalle 2005. Museoiden verkkonäyttelyt historian oppimateriaaleina. [Online Museum Exhibitions as Learning Material in Teaching History.] Master's thesis. Helsinki: Department of Education, University of Helsinki. Available at http:// www.kotikone.fi/kallekallio/gradu2.pdf, last accessed on February 5, 2014.

Kaplan, Merrill 2013. Curation and Tradition on Web 2.0. In: T. J. Blank \& R. G. Howard (eds.) Tradition in the Twenty-First Century. Locating the Role of the Past in the Present. Logan: Utah State University Press, pp. 123-148.

Kean, Hilda \& Ashton, Paul 2009. Introduction: People and their Pasts and Public History Today. In: P. Ashton \& H. Kean (eds.) People and their Pasts: Public History Today. London: Palgrave Macmillan.

Kramer, Anne-Marie 2011. Kinship, Affinity and Connectedness: Exploring the Role of Genealogy in Personal Lives. Sociology, Vol. 45, No. 3, pp. 379-395. doi: 10.1177/0038038511399622.

Larsen, Jonas \& Urry, John \& Axhausen, Kay 2008. Coordinating Face-to-Face Meetings in Mobile Network Societies. Information, Communication \& Society, Vol. 11, No. 5, pp. 640-658. http://dx.doi.org/10.1080/13691180802126752.

Latvala, Pauliina 2005. Katse menneisyyteen. Folkloristinen tutkimus suvun muistitiedosta. [A Glimpse into the Past: A Folkloristic Investigation into Oral History of the Family.] Helsinki: Suomalaisen Kirjallisuuden Seura.

Logan, William \& Reeves, Keir 2011 [2009]. Introduction: Remembering Places of Pain and Shame. In: W. Logan \& K. Reeves (eds.) Places of Pain and Shame. Dealing with "Difficult Heritage". London \& New York: Routledge, pp. 1-14. 
Maj, Anna \& Riha, Daniel 2009. Introduction. In: A. Maj \& D. Riha (eds.) Digital Memories: Exploring Critical Issues. Oxford: Inter-Disciplinary Press, pp. 1-9. Available at http://www.inter-disciplinary.net/wp-content/uploads/2009/12/DigMem-1.3d.pdf, last accessed on February 5, 2014.

Margry, Peter Jan \& Sánchez-Carretero, Cristina 2011. Introduction: Rethinking Memorialization: The Concept of Grassroots Memorials. In: P. J. Margry \& C. SánchezCarretero (eds.) Grassroots Memorials. The Politics of Memorializing Traumatic Death. New York \& Oxford: Berghahn, pp. 1-48.

Markham, Annette \& Buchanan, Elizabeth 2012. Ethical Decision-Making and Internet Research: Recommendations from the AoIR ethics working committee (Version 2.0). Available at http://aoir.org/reports/ethics2.pdf, last accessed on February 5, 2014.

Miller, Montana 2012. Face-to-Face with the Digital Folk: The Ethics of Fieldwork on Facebook. In: T. J. Blank (ed.) Folk Culture in the Digital Age: The Emergent Dynamics of Human Interaction. Logan: Utah State University Press, pp. 212-230.

Nielsen, Jakob 2006. Participation Inequality: Encouraging More Users to Contribute. Available at http://www.nngroup.com/articles/participation-inequality/, last accessed on February 5, 2014.

Peltonen, Ulla-Maija 2003. Muistin paikat. Vuoden 1918 sisällissodan muistamisesta ja unohtamisesta. [Sites of Memory: On Remembering and Forgetting the 1918 Civil War in Finland.] Helsinki: Suomalaisen Kirjallisuuden Seura.

Pietrobruno, Sheenagh 2013. YouTube and the Social Archiving of Intangible Heritage. New Media \& Society, Vol. 15, No. 8, pp. 1259-1276. doi:10.1177/1461444812469598.

Rosenzweig, Roy \& Thelen, David 1998. The Presence of the Past: Popular Uses of History in American Life. New York \& Chichester: Columbia University Press.

Samuel, Raphael 1994. Theatres of Memory: Past and Present in Contemporary Culture. London \& New York: Verso.

Srigley, Katrina \& Zembrzycki Stacey 2009. Remembering Family, Analyzing Home: Oral History and the Family. Oral History Forum d-histoire orale 29, pp. 1-19. Available at http://www.oralhistoryforum.ca/index.php/ohf/issue/view/10, last accessed on February 5, 2014.

Sturken, Marita 2007. Tourists of History: Memory, Kitsch, and Consumerism from Oklahoma City to Ground Zero. Durham \& London: Duke University Press.

Suominen, Jaakko 2009. Johdannoksi: netin kulttuurihistoriaa. [Introduction: A Cultural History of the Internet.] In: P. Saarikoski \& J. Suominen \& R. Turtiainen \& S. Östman (eds.) Funetista Facebookiin: Internetin kulttuurihistoria. [From Funet to Facebook: A Cultural History of the Internet.] Helsinki: Gaudeamus, pp. 7-22.

Suominen, Jaakko 2013. Johdanto: Sosiaalisen median aika. [Introduction: The Era of Social Media.] In: J. Suominen \& S. Östman \& P. Saarikoski \& R. Turtiainen (eds.) Sosiaalisen median lyhyt historia. [A Brief History of Social Media.] Helsinki: Gaudeamus, pp. 9-24. Available at http://www.gaudeamuskirja.fi/wp-content/ uploads/2013/11/Sisallys_Sosiaalisen_median_lyhyt_historia.pdf, last accessed on February 5, 2014.

Torsti, Pilvi 2012. Suomalaiset ja historia. [The Finns and History.] Helsinki: Gaudeamus. Thomson, Alistair 2007. Four Paradigm Transformations in Oral History. Oral History Review, Vol. 34, No. 1, pp. 49-70. http://dx.doi.org/10.1525/ohr.2007.34.1.49. 
Tredinnick, Luke 2013. The Making of History: Remediating Historicized Experience. In: T. Weller (ed.) History in the Digital Age. London \& New York: Routledge, pp. 39-60.

Van Dijck, José 2007. Mediated Memories in the Digital Age. Stanford: Stanford University Press.

Westerlund, Lars 2004. Sotaoloissa vuosina 1914-1922 surmansa saaneet. [Victims of War between 1914 and 1922.] Valtioneuvoston kanslian julkaisusarja 10/2004. Helsinki: Prime Minister's Office. Available at http://vnk.fi/julkaisukansio/2004/ j10-sotaoloissa-1914-22-surmansa-saaneet/pdf/fi.pdf, last accessed on February 5, 2014.

Winter, Jay 2003 [1995]. Sites of Memory, Sites of Mourning: The Great War in European Cultural History. Cambridge: Cambridge University Press.

Ylikangas, Heikki 1993. Tie Tampereelle. Dokumentoitu kuvaus Tampereen antautumiseen johtaneista taisteluista Suomen sisällissodassa 1918. [The Road to Tampere: A Documented Account of the Battles That Led to the Surrendering of Tampere during the 1918 Finnish Civil War.] Porvoo \& Helsinki \& Juva: WSOY.

\section{ONLINE SOURCES}

\section{Blogs and discussion forums}

Fellmanin pelto-blogi (Fellman Field blog). http://www.ess.fi/?category=5034, no longer available.

Hongisto, Pekka 6.4.2013. Arvoisa isotäti. [Respected Great-Aunt.] Fellmanin pelto blog. Available at http://www.ess.fi/?article=410082, last accessed on February 5, 2014.

Päivä Tampereella 1918. [A Day in Tampere in 1918.] Available at http://tampere1918. blogspot.fi/, last accessed on February 5, 2014.

Olin-Arvola, Kaija 31.3.2012. Hei, Me vaikutetaan! II. [Hi, We Are Making a Difference!] Uusi Suomi [New Finland] newspaper. Available at http://kaijaolinarvola. puheenvuoro.uusisuomi.fi/101869-hei-me-vaikutetaan-ii\#comment-1443609, last accessed on February 5, 2014.

Olin-Arvola, Kaija 11.11.2011. Isä tekee mitä haluaa. [Father Does as He Pleases.] Kotikuusesta. [From the Home Fir Tree.] Available at http://kotikuusestahannesolin. blogspot.fi/2011/11/isa-tekee-mita-haluaa.html, last accessed on February 5, 2014.

Olin-Arvola, Kaija 15.10.2010. ¡El pueblo unido, jamás será vencido! Aamulehti - blog. Available at http://aamulehdenblogit.ning.com/profiles/blogs/el-pueblo-unidojamas-sera, last accessed on February 5, 2014.

Olin-Arvola, Kaija 12.4.2010. Ida Matilda Lindell - Arjen Sankari. Muistelmia mummustani. [Ida Matilda Lindell: An Ordinary Hero. Reminiscences of My Grandmother.] Available at http://idamatildalindell.blogspot.fi/, last accessed on February $5,2014$. 
Olin-Arvola, Kaija 19.12.2009. Kolmannessa polvessa. [In the Third Generation.] Kansan Uutiset verkkolehti. Available at http://www.kansanuutiset.fi/scripts/edoris/ edoris.dll?app=server\&com=sqlxml\&tem=d_aihepuu.tpl\&topicid=17363\&selec ted=17387, last accessed on February 5, 2014.

http://www.suomi24.fi/

\section{Facebook}

Helsti, Hilkka, personal page. Available at https://www.facebook.com/hilkka.helsti?fref=ts, last accessed on April 30, 2013.

Baron Carl Gustav Emil von Mannerheim. Available at https://www.facebook.com/pages/ Baron-Carl-Gustav-Emil-von-Mannerheim/26750023086?fref=ts, last accessed on February 5, 2014.

Fellmanin pelto - 22000 ihmisen elvää monumentti. [Fellman Field - Living Monument of 22000 People.] Available at https://www.facebook.com/FellmaninPelto?fref=ts, last accessed on February 5, 2014.

Kansan Arkisto. [People's Archive.] Available at https://www.facebook.com/pages/ Kansan-Arkisto/10150115579865717?fref=ts, last accessed on February 5, 2014.

KIITOS 1919. [Thank you, 1918.] Available at https://www.facebook.com/Kiitos1918?fref=ts, last accessed on March 12, 2014.

Korvela, Marko, personal page. Available at https://www.facebook.com/marko.korvela?fref=ts, last accessed on March 12, 2014.

Mannerheim. Available athttps://www.facebook.com/pages/Mannerheim/23864107766?fref=ts, last accessed on March 12, 2014.

Punakaartilaisen muistolle. [For the Memory of a Red.] No longer available.

Punavankien perilliset. [The Descendants of Red Prisoners of War.] No longer available. Suojeluskunta (Skyddskår) järjestön muistolle. [Legacy of the White Civil Guard.] Available at https://www.facebook.com/groups/55569931609/?fref=ts, last accessed on February 5, 2014.

Suomen Työväen Järjestyskaartin Perinneyhdistys ry. [The Tradition Association of the Finnish Workers' Guard.] Available at https://www.facebook.com/pages/ Suomen-Ty\%C3\%B6v\%C3\%A4en-J\%C3\%A4rjestyskaartin-Perinneyhdistysry/215576731804579?fref=ts, last accessed on February 5, 2014.

\section{Websites}

Arjenhistoria.fi. [Everyday History.] http://www.arjenhistoria.fi/, last accessed on February $5,2014$.

Epooq.net. http://www.epooq.net/selfregistration/epooqlogin, last accessed on March 26, 2013.

Geocaching: Suomen sisällissota 1918. [Geocaching: Finnish Civil War 1918.] http:// www.geocaching.com/bookmarks/view.aspx?guid=7ed92718-0511-4fdb-a10543799dda39d1, last accessed on February 5, 2014. 
Information Portal to European Sites of Remembrance. http: //www.memorialmuseums. org/pages/home, last accessed on February 5, 2014.

Kansan arkisto: 1918 Kansalaissodan kuvia. [People's Archive: Photographs of the 1918 Civil War.] http://www.kansanarkisto.fi/kanssota/, last accessed on February 5, 2014.

Koskesta voimaa. [The Power of the Rapids, Tampere 1918.] http://www.uta.fi/yky/ arkisto/koskivoimaa/valta/1918-40/1918tap.htm, last accessed on February 5, 2014.

Lotta Svärd Säätiö. [Lotta Svärd Foundation.] http://www.lottasaatio.fi/, last accessed on February 5, 2014.

Memoro: The Bank of Memories. http://www.memoro.org/index.php, last accessed on February 5, 2014.

Museot.fi 23.4.2008: Museoiden näyttelyt kertovat vuoden 1918 tapahtumista. [Museum Exhibitions Tell about the 1918 Civil War.] http://www.museot.fi/uutiset.php?ai d=9676\&hakustr=kokoelmiin, last accessed on February 5, 2014.

National Archives, 1918. Kansalaissota asiakirjonen kertomana. [The Civil War Presented in Documents.] http://www.narc.fi/1918verkkonayttely/index.html, last accessed on February 5, 2014.

Nautelankosken museo, Vaiettu vuosi 1918. Näkökulmia sisällissotaan. [Nautelankoski Museum: The Silenced Year 1918, Perspectives into the Civil War.] http://www. nautelankoski.net/1918.php, last accessed on March 12, 2014.

Oral History in the Digital Age. http://ohda.matrix.msu.edu/, last accessed on February 5, 2014.

The Polynational War Memorial. http://www.war-memorial.net, last accessed on February 5, 2014.

Suomen Puolustusvoimat, Sotamuseo. [The Finnish Defence Forces Military Museum.] www.sotamuseo.fi, last accessed on February 5, 2014.

Suomen sisällissotamuseo. [The Finnish Civil War Association.] http://www. sisallissotamuseo.fi/, last accessed on February 5, 2014.

Tampere 1918, Museokeskus Vapriikki, Tampere. [Tampere 1918: Museum Centre Vapriikki, City of Tampere.] http://vapriikki.fi/tampere1918/, last accessed on February 5, 2014.

Työväenmuseo Werstas: Punaisten muistomerkit. [The Finnish Labour Museum Werstas, Memorials of the Reds.] http://www.tkm.fi/pm_etusivu.htm, last accessed on February 5, 2014.

Suomen sotasurmat 1914-1922. [War Victims in Finland 1914-1922.] http://vesta.narc. fi/cgi-bin/db2www/sotasurmaetusivu/main?lang=en, last accessed on February 5, 2014.

Suomen vapaussota 1918. [The Tradition Union of the War of Freedom 1918.] http:// www.vapaussota.com/vapaussota.html, last accessed on February 5, 2014.

Varkauden museo, Varkaus 1918. [Varkaus Museum, Varkaus and the Year 1918.] No longer available.

Suomen Vapaussota. [Freedom War.] http://vapaussota.fi/, last accessed on February 5, 2014.

Veteraaniperinne. [Tradition of War Veterans.] http://www.veteraaniperinne.fi, last accessed on February 5, 2014. 
The World Summit Award. http://www.wsis-award.org/winner/epooq-80020110609, last accessed on February 5, 2014.

\section{Video and multimedia}

Vapaussota 1918: Kapina, sisällissota, kansalaissota. [Freedom War 1918: Rebellion, Civil War, People's War.] Multimedia, WSOY Pro 2008: http://www.vapaussota. fi/multimedia/, last accessed on February 5, 2014.

Kuolemaantuomitun hyvästijättö. [Farewell of a Person Condemned to Death.] 17.07.2008. http://www.youtube.com/watch?v=zRL2TgPWJAA/, last accessed on February 5, 2014. 